Original Research Paper

\title{
Biodegradation of 2, 4 Dichlorophenol
}

\author{
${ }^{1}$ Taghreed Al-Khalid and ${ }^{2}$ Muftah H. El-Naas \\ ${ }^{I}$ Department of Chemical Engineering, UAE University, Al-Ain, UAE \\ ${ }^{2}$ Gas Processing Center, Qatar University, Doha, Qatar
}

Article history

Received: 30-11-2016

Revised: 21-12-2016

Accepted: 08-03-2017

Corresponding Author:

Muftah H. El-Naas

Gas Processing Center, Qatar

University, Doha, Qatar

Email:muftah@qu.edu.qa

\begin{abstract}
The present study focuses on the optimization of process parameters of the aerobic biodegradation of 2, 4 Dichlorophenol (2, 4 DCP) by a commercial strain of $P$. putida immobilized in PVA gel matrix, using design of experiments by Response Surface Methodology (RSM). The degradation rates obtained from these experiments were used to evaluate the effects of the main factors and their interactions during the biodegradation of 2, 4 DCP. An effective quadratic regression model predicting the rate in terms of the main independent variables, namely temperature, initial $\mathrm{pH}$ and initial concentration of 2, 4 DCP, was developed. The optimum conditions for DCP degradation were obtained as follows: Temperature $32.6^{\circ} \mathrm{C}, \mathrm{pH} 5.0$ and initial DCP concentration 70.5 $\mathrm{mg} \mathrm{L}^{-1}$, resulting in a maximum predicted degradation rate of $41.8 \mathrm{mg} \mathrm{L}^{-1}$ $\mathrm{h}^{-1}$. Under these optimized conditions, a degradation rate of $40.1 \mathrm{mg} \mathrm{L}^{-1} \mathrm{~h}^{-1}$ was experimentally obtained, thus validating the model.
\end{abstract}

Keywords: Biodegradation, Immobilization, Optimization, Response Surface Methodology, Box-Behnken Design

\section{Introduction}

Chemical and petroleum industries generate a wide range of highly toxic organic substances, which have led to serious environmental impacts. The effluents of these industries are rich in aromatic organic compounds that are rather difficult for natural degradation and thus continue to exist as an environmental threat. Upon long range transportation, they will bioaccumulate in human and animal tissues. Organic pollutants are a set of chemicals that can put human health at high risk (Chung et al., 2003; Nair et al., 2008; Liu et al., 2009) and many aromatic compounds show carcinogenic, teratogenic or mutagenic properties (Zhao et al., 2009). Therefore, these compounds must be pretreated into biodegradable or less toxic compounds.

Chlorophenols are xenobiotic contaminants, which form a significant part of all organic chemicals either produced or used by many industries such as petrochemicals, oil refineries, plastics, insulation materials, pesticides, biocides, pulp and wood preservers (Kusic et al., 2011). Some of them (in particular mono-chlorophenols) can be formed during the chlorination of wastewaters and drinking water for disinfection and from the breakdown of pesticides and other chlorinated aromatic compounds (Ye and Shen, 2004; Sahinkaya and Dilek, 2006; Olaniran and Igbinosa,
2011; Majumder and Gupta, 2007; Menale et al., 2012). Due to their high toxicity, strong odor emission, persistence in the environment and suspected carcinogenicity, chlorophenols pose critical ecological issues (Kusic et al., 2011; Wang et al., 2007a). Most of the chlorophenols have been included in the US Environmental Protection Agency EPA list of priority pollutants (Kusic et al., 2011; Bhattacharya and Banerjee, 2008; Basak et al., 2013). The environmental regulations in many countries specify the maximum allowable concentration of phenols in the industrial effluents to be less than $1 \mathrm{mg} \mathrm{L}{ }^{-1}$ (Kusic et al., 2011; Bapat et al., 2008). However, higher concentrations were frequently found in contaminated environments, with reported levels of chlorophenols ranging from 0.15 to $200 \mathrm{mg} \mathrm{L}^{-1}$ and even more (Angelini et al., 2011). The UAE legislations are very strict, with a limit of the total phenols in industrial water set to $0.1 \mathrm{mg} \mathrm{L}^{-1}$ (Al Zarooni and Elshorbagy, 2006).

Therefore, to save the soils and aqueous ecosystems, pretreatment of industrial wastewater has been mandatory worldwide. Phenolic compounds have been reported to be highly stable due to the difficulty of cleaving the benzene ring (Annadurai et al., 2008). However, several microorganisms can tolerate phenols and use them as a source of carbon and energy (Kılıç, 
2009; Farrell and Quilty, 2002). As for chlorophenols, they are even more resistant to biodegradation as the enzyme activity needed for ring cleavage could be suppressed by the chloride atom (Wang et al., 2007a; Papazi and Kotzabasis, 2007).

Biological treatment of phenols has emerged as an increasingly important method in pollution management (Liu et al., 2009; Wang et al., 2007b; El-Naas et al., 2010a). Compared with physico-chemical methods, the biodegradation method of phenols removal is widely preferred as a more environmental friendly and cost effective approach, due to the possibility of complete mineralization of phenol or its derivative (Liu et al., 2009; El-Naas et al., 2009; Kargi and Eker, 2005). This results in complete conversion of a compound to its inorganic mineral constituents (Nair et al., 2008), with harmless end products and minimum secondary metabolites (Sridevi et al., 2011). Novel bioremediation strategies are rising as a favorable and most promising green technology for the treatment of wastewaters (Menale et al., 2012; Shourian et al., 2009).

Many strains of aerobic bacteria, including Pseudomonas putida, have been proven effective in utilizing aromatic compounds as the only source of carbon and energy (El-Naas et al., 2010a; 2009; Tziotzios et al., 2005). In recent years, $P$. putida has been a focus of research as the most widely used type of bacteria for phenols biodegradation and many studies have been reported on its utilization in free and immobilized forms, using different types of bioreactors (El-Naas et al., 2009). Immobilization is an effective technique that provides significant protection to the biomass from the harmful influences of the harsh environment imposed by the high substrate concentrations; reutilization of the biomass is an added value (El-Naas et al., 2010a; 2009; 2010b). Compared with free cells, the benefits of immobilization extend to include distinct stability and high degradation efficiency (Sheeja and Murugesan, 2002).

Since the biodegradation of chlorophenols is highly dependent on many conditions, such as $\mathrm{pH}$, temperature, initial substrate concentration and others, it is critical to evaluate the effects of the key influencing parameters. Optimization of the biodegradation conditions is a prerequisite to large-scale applications of biodegradation processes (Basak et al., 2013). In recent years, optimization techniques have been employed to tackle important issues of contaminated site management (Bhattacharya et al., 2009). It is extremely tedious and time-consuming to go through such work using the conventional "one-factor-at-a-time" technique. Furthermore, this method does not account for the different interactions between two or more factors and therefore the results might be misinterpreted (Basak et al., 2013; Sridevi et al., 2011; Wu et al., 2009). In contrast, statistical design of experiments can optimize all the affecting parameters, saving a lot of time and money by considerably decreasing the number of trials needed to investigate the effects of multiple variables (Basak et al., 2013; Rigas et al., 2005).

Response Surface Methodology (RSM) is a graphical statistical modeling technique that is the most widely used for bioprocess optimization (Annadurai et al., 2002). It requires a prior knowledge of the process to obtain a mathematical model based on the relationship between a set of controllable experimental factors and observed results (Sridevi et al., 2011; Bhattacharya and Banerjee, 2008; Annadurai et al., 2008), with the great advantage that the interaction among the influencing variables is inherent in the model and can be evaluated with limited number of experiments (Annadurai et al., 2002). This optimization method involves three major steps: Performing the statistically designed experiments, estimating the coefficients in a mathematical model and validating the model by response prediction (Annadurai et al., 2008; 2002).

Biotreatment process optimization by statistical experimental design has been well documented (Annadurai et al., 2008; Sridevi et al., 2011; Sheeja and Murugesan, 2002; Wu et al., 2009; Rigas et al., 2005; Cutright and Meza, 2007; Agarry et al., 2008b; Yao et al., 2009). However few studies were reported as to chlorophenols removal (Kusic et al., 2011; Bhattacharya et al., 2009). Kusic et al. (2011) applied the Box-Behnken experimental design inherent in the RSM to evaluate the feasibility of UV/ferrioxalate system for the degradation of 4-Chlorophenol (4 CP) as a model wastewater pollutant. Kargi and Eker (2005) used a Box-Wilson design to optimize the removal of 2 , 4 DCP from synthetic wastewater in a rotating perforated tube biofilm reactor by activated sludge culture supplemented with $P$. putida. Bhattacharya and Banerjee (2008) and Bhattacharya et al. (2009) employed RSM for the study of enzyme mediated biodegradation of 2,4 DCP. Basak et al. (2013) employed the Taguchi design of experiments to optimize the degradation of $4 \mathrm{CP}$ by a yeast strain of Candida tropicalis.

The objective of the present study is to evaluate the RSM efficiency in optimizing the biodegradation of 2, 4 DCP in wastewater to achieve highest degradation rate. Batch experiments were performed in a Spouted Bed Bioreactor (SBBR) using a commercial consortium, in which $P$. putida is dominant, immobilized in Polyvinyl Alcohol (PVA) gel matrix. The classical singleparameter selection technique was initially used to approach the optimum range of each main factor. Following, the RSM with Box-Behnken design was applied to evaluate the effects of significant factors and their interactions, in the degradation of 2, 4 DCP and to find the optimal conditions for maximized degradation rates as obtained from batch experiments in the SBBR. The goal was to develop an effective quadratic regression model that is capable of predicting the rate in terms of the main independent variables, namely temperature, initial $\mathrm{pH}$ and initial concentration. 


\section{Materials and Methods}

Details of the procedures and techniques utilized in the preparation of the biomass as well as bacterial immobilization and acclimatization have been published in a previous study (El-Naas et al., 2009). A brief summary of these procedures is given below.

\section{Reagents}

Analytical grade 2, 4 DCP was obtained from Sigma-Aldrich, Germany with purity greater than $99 \%$. Synthetic 2, 4 DCP solutions ware prepared at the required concentrations by adding predetermined amount of the organic substance to nutrient solution, which had a total concentration of $825 \mathrm{mg} \mathrm{L}^{-1}$ of the essential mineral nutrients as shown in Table 1 . The solid 2, 4 DCP was dissolved by heating at $35^{\circ} \mathrm{C}$. The prepared solutions were then stored in dark containers in closed cabinets to avoid light oxidation of 2, 4 DCP. All other used chemicals and PVA powder were of analytical grade and obtained from BDH Chemicals, UK.

\section{Preparation of Microbial Culture}

The bacterium used was a specific strain of $P$. putida, obtained in cereal form (AMNITE P300) from Cleveland Biotech Ltd., UK. Detailed description of the bacteria preparation can be found elsewhere (El-Naas et al., 2009).

\section{Immobilization}

The bacteria cells were immobilized in a homogenous $10 \mathrm{wt} \%$ PVA gel mixture, which is reported to result in good quality and high porosity of the polymer matrix (El-Naas et al., 2009; 2010b). The immobilization technique aimed at increasing the mechanical strength of the polymer structure by inducing cross-linking with five repeated cycles of freezingthawing. The frozen molds were divided into three portions, each of about $350 \mathrm{~mL}$ and cut to the specified size of $1,0.5$ and $0.25 \mathrm{~cm}^{3}$ cubes, respectively. Detailed description of the biomass immobilization process can be found elsewhere (El-Naas et al., 2009).

Table 1. Composition of nutrient mineral medium

\begin{tabular}{|c|c|}
\hline Component & Concentration, $\mathrm{mg} \mathrm{L}^{-1}$ \\
\hline $\mathrm{MgSO}_{4} \cdot 7 \mathrm{H}_{2} \mathrm{O}$ & 300 \\
\hline $\mathrm{K}_{2} \mathrm{HPO}_{4}$ & 250 \\
\hline $\mathrm{CaCl}_{2} \cdot 2 \mathrm{H}_{2} \mathrm{O}$ & 150 \\
\hline$(\mathrm{NH} 4)_{2} \mathrm{CO}_{3}$ & 120 \\
\hline $\mathrm{FeSO}_{4} \cdot 7 \mathrm{H}_{2} \mathrm{O}$ & 3.5 \\
\hline $\mathrm{ZnSO}_{4} \cdot 7 \mathrm{H}_{2} \mathrm{O}$ & 1.3 \\
\hline $\mathrm{MnCl}_{2} \cdot \mathrm{H}_{2} \mathrm{O}$ & 0.13 \\
\hline $\mathrm{CuSO}_{4} .5 \mathrm{H}_{2} \mathrm{O}$ & 0.018 \\
\hline $\mathrm{CoCl}_{2} \cdot 6 \mathrm{H}_{2} \mathrm{O}$ & 0.015 \\
\hline $\mathrm{Na} 2 \mathrm{MnO} .2 \mathrm{H}_{2} \mathrm{O}$ & 0.013 \\
\hline Total & 824.98 \\
\hline
\end{tabular}

\section{Acclimatization of Bacteria}

Phenol has been reported for its inhibitory effect to bacteria growth at concentrations above $0.05 \mathrm{~g} \mathrm{~L}^{-1}$ (El-Naas et al., 2010b; Bajaj et al., 2008). Therefore, acclimatization (adaptation) of the microbial cultures to phenols is an important step for efficient biodegradation of these compounds due to their high toxicity to microorganisms (El-Naas et al., 2009; 2010b; Bajaj et al., 2008; Al-Khalid and El-Naas, 2012; Khan et al., 2011). Pre-adaptation of the biomass to the chlorophenols is known to enhance the rate and the extent of biodegradation of those compounds (Bhattacharya and Banerjee, 2008; Kargi and Eker, 2005). The study was carried out with freshly-prepared bacteria adapted directly to 2, 4 DCP. Each portion of the three different sizes of the immobilized bacteria was suspended in a glass bottle to a total volume of about $1100 \mathrm{~mL}$ in nutrient solution prepared as shown in Table 1 and containing $25 \mathrm{mg} \mathrm{L}^{-1}$ of DCP as a source of organic carbon. The bottles were immersed in a water bath to control the temperature at $30^{\circ} \mathrm{C}$. A continuous supply of air into the bottles was required to promote mixing and also secure excess oxygen to foster aerobic condition. The bacteria were then gradually acclimatized to DCP by a stepwise increase in the DCP from 25 to $50,100,150$, up to $200 \mathrm{mg} \mathrm{L}^{-1}$ over a period of 5 days.

\section{Analytical Methods}

The concentration of 2, 4 DCP in the biomass-free samples was determined using Shimadzu Gas Chromatograph, Model GC 2014, Japan, equipped with capillary column and Electron Capture Detector (ECD). The injector and detector temperatures were adjusted to 275 and $300^{\circ} \mathrm{C}$, respectively. The column temperature program started at $120^{\circ} \mathrm{C}$ and was increased to $220^{\circ} \mathrm{C}$ at a rate of $25^{\circ} \mathrm{C} \min ^{-1}$. Measurements were made after filtering the $1 \mu \mathrm{L}$ sample through $0.45 \mu \mathrm{m}$ GHP Acrodisc filter, then injecting into the GC. A calibration curve of standard solutions of known concentrations was first established and then used as a basis to determine the residual concentration. The accuracy of the GC was continually checked every $4 \mathrm{~h}$ of continuous operation by a standard solution. Statistically, averages of duplicate or triplicate experimental results were reported in the study, with the standard deviation ranging from 2 to $5 \%$ of the reported average. A portable pH-meter, Sartorius PT 10, Germany, with accuracy of \pm 0.005 and readability of \pm 0.01 , was used for $\mathrm{pH}$ measurements. In the present study, Minitab16 was used for the design of experiments and analysis of the results.

\section{Batch Removal of 2, 4 DCP in SBBR using PVA- Gel Immobilized Bacteria}

After acclimatization and before starting the runs in the SBBR, the PVA gel cubes were soaked in the 
substrate solution of required concentration for $10 \mathrm{~min}$, then the soaking solution was decanted. This step is needed to reduce the dilution effect in the reactor due to the water inherent in the PVA gel particles. The reactor was initially filled with standard mineral medium, prepared according to Table 1, which contained the required concentration of the substrate. PVA gel cubes with immobilized bacteria were added in a ratio of 30 vol\% of the working volume (about 11 ) in the reactor. The SBBR configuration has the advantage of more efficient mixing over conventional bubble column bioreactors (El-Naas et al., 2010a; 2010b). The efficient intense mixing is due to the cyclic motion of particles within the bed, which results from an air jet injected through an orifice in the bottom of the reactor. The spouted bed bioreactor is made of Plexiglas and has a total volume of $1.1 \mathrm{l}$. The temperature control was achieved by circulating water into a jacket surrounding the reactor, from a water bath set at the desired temperature. A continuous flow of air into the reactor, at a pre-specified flow rate, was introduced to ensure intense mixing and to provide sufficient oxygen to maintain aerobic condition. A schematic diagram of the spouted bed reactor with dimensions is shown in Fig. 1.

When needed, the $\mathrm{pH}$ was adjusted by adding few drops of either $\mathrm{HCl}$ or $\mathrm{NaOH}$ according to the desired value. Samples for analysis of residual 2, 4 DCP concentrations were withdrawn at regular time intervals. To confirm that the removal efficiency was due to the biodegradation effect and not to other abiotic effects such as stripping or adsorption on the carrier, some blank experiments were run under the same operating conditions as explained in the results and discussion section.

\section{Single Factor Batch Experiments to Identify the Optimum Range of Different Factors}

This study was based on a classical single-parameter selection technique to approach the optimal range of each main variable (temperature $\mathrm{T}$, initial $\mathrm{pH}$ value, initial DCP concentration $\mathrm{C}_{0}$, size of immobilized particles and inlet air flow rate AFR). These factors were found critical in biodegradation processes by many previous studies (Menale et al., 2012; Bhattacharya and Banerjee, 2008; El-Naas et al., 2010a; 2009; 2010b; Sheeja and Murugesan, 2002; Bhattacharya et al., 2009; Agarry et al., 2008b; Yao et al., 2009; Agarry et al., 2008a). Subsequently, this was followed by optimization of the first three factors by the response surface methodology.

Experiments were conducted with different initial 2, 4 DCP concentrations $\left(25,50,100,150,200 \mathrm{mg} \mathrm{L}^{-1}\right)$, temperature $\left(22,25,30,35,40{ }^{\circ} \mathrm{C}\right)$, the initial $\mathrm{pH}$ value $(5,6,7,8,9,10)$. Three levels were considered for PVA particle size $\left(0.25,0.5,1 \mathrm{~cm}^{3}\right)$ and five levels of air flow rate $\left(1,2,3,4,5 \mathrm{~L} \mathrm{~min}^{-1}\right)$ for a total working volume of
$1000 \mathrm{~mL}$. In each experiment, the factor under study was changed, with the other factors fixed at their normal values. At the end of this study, the PVA particle size and the inlet air flow rate were fixed, whereas the range of temperature, $\mathrm{pH}$ and initial DCP concentration were chosen to be further optimized by RSM.
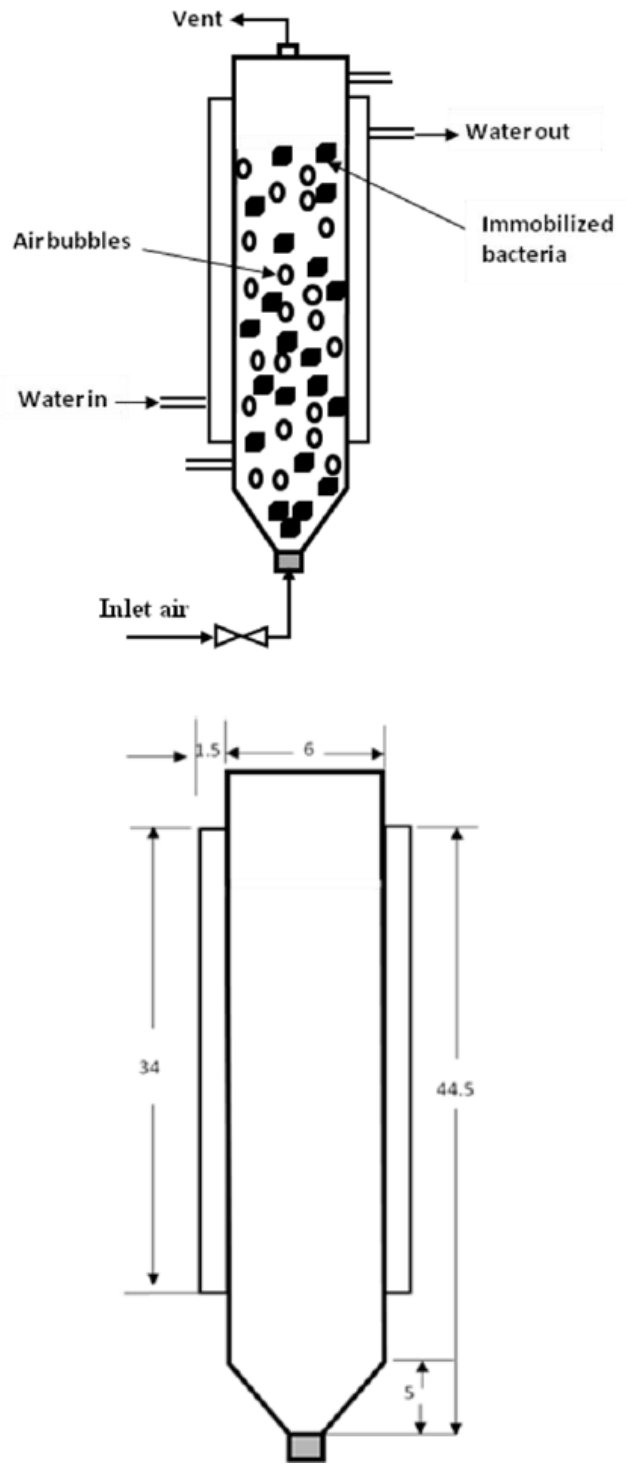

Fig. 1. A schematic diagram of the spouted bed bioreactor (all dimensions in $\mathrm{cm}$ )

Table 2. Experimental design range and levels of the design factors

\begin{tabular}{lrrr}
\hline & \multicolumn{3}{c}{ Coded values } \\
& \multicolumn{1}{c}{$-\boldsymbol{c}$} \\
Factors & -1 & 0 & \multicolumn{1}{c}{1} \\
\hline A: Temperature, ${ }^{\circ} \mathrm{C}$ & 25 & 30 & 35 \\
B: Initial pH value & 5 & 7 & 9 \\
C: Initial DCP concentration, $\mathrm{mg} / \mathrm{l}$ & 25 & 75 & 125 \\
\hline
\end{tabular}




\section{Response Surface Methodology (RSM)}

From the above experiments, the optimal ranges of the three main variables were determined to maximize DCP degradation with RSM. Minitab 16 Statistical Software was used to apply a Box-Behnken factorial design with three factors, each at three levels, in addition to three replicates at the center point. A second order response model was obtained that describes DCP degradation based on the main and interactive effects of these parameters. The range and the levels of the process variables under study are given in Table 2: Temperature $(25,30$ and $\left.35^{\circ} \mathrm{C}\right), \mathrm{pH}(5,7$ and 9$)$ and initial DCP concentration $(25$, 75 and $125 \mathrm{mg} \mathrm{L}^{-1}$ ), which were represented in the model as critical parameters $\mathrm{A}, \mathrm{B}$ and $\mathrm{C}$, respectively.

\section{Results and Discussion}

\section{Single Factor Batch Experiments to Identify the Optimum Range of Different Factors}

\section{Confirmation of Biodegradation}

Since biodegradation experiments are usually performed at $30^{\circ} \mathrm{C}$ with continuous aeration, there is a need to investigate and exclude any possible contribution to the overall biodegradation rate by both stripping of 2 , 4 DCP evaporation and adsorption. Control experiments were conducted to evaluate the contribution of stripping and adsorption on bacteria-free PVA to the overall biodegradation rate. Some runs involved nutrients added to the DCP solution to check the less likely possible contribution of external bacteria to the biodegradation of DCP. These control tests were performed under identical operating conditions to those employed in the biodegradation experiments. The losses ranged from 2.5 to $7 \%$, which confirms that the 2, 4 DCP removal is mainly attributed to biodegradation by immobilized $P$. putida.

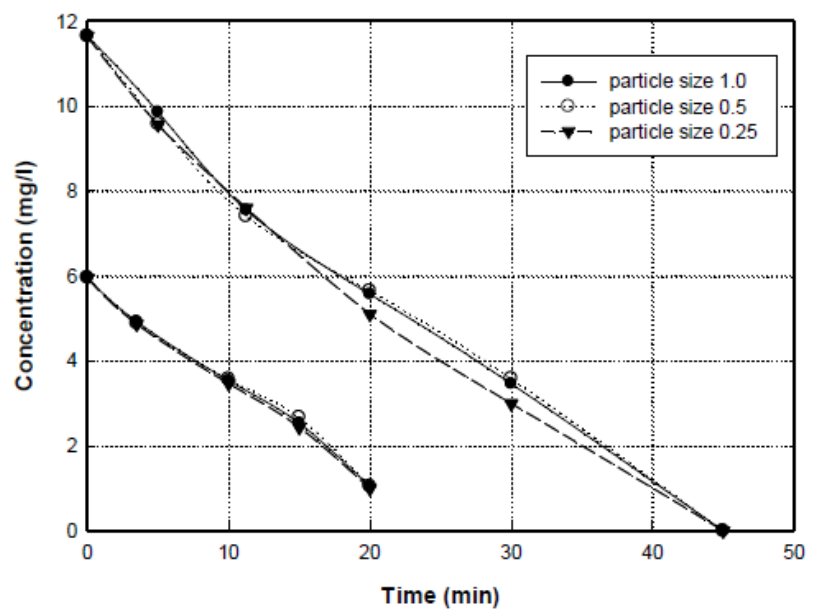

(a)

\section{Effect of PVA Particle Size}

To investigate the effect of PVA particle size of 1.0, 0.5 and $0.25 \mathrm{~cm}^{3}$, experiments were conducted for a range of DCP initial concentration $(5,10,25,50$ and 100 $\left.\mathrm{mg} \mathrm{L}^{-1}\right)$. The initial $\mathrm{pH}$ was kept at the initial value without any adjustment in the range of 8.2-8.4, while the temperature and AFR were fixed at $30^{\circ} \mathrm{C}$ and $3 \mathrm{~L} \mathrm{~min}^{-1}$, respectively. It is expected that mixing inside the reactor would be improved upon reducing the particle size and mass transfer would be enhanced probably by lowering diffusion limitations and increasing the surface area, which makes the biomass more accessible to the substrate (El-Naas et al., 2010b; Sheeja and Murugesan, 2002). This was observed to be more pronounced at low initial concentrations $\left(10,25\right.$ and $\left.50 \mathrm{mg} \mathrm{L}^{-1}\right)$ rather than high concentration of $100 \mathrm{mg} \mathrm{L}^{-1}$ as shown by Fig. 2 . This could be justified by the fact that the highly porous structure of the PVA particles, coupled with high bulk concentration of the substrate, will result in a negligible resistance to mass transfer (El-Naas et al., 2009).

Figure 3 presents a comparison of the three particle sizes for an inlet AFR of $1 \mathrm{~L} \mathrm{~min}^{-1}$ (a) and $5 \mathrm{~L} \mathrm{~min}^{-1}$ (b). According to El-Naas et al. (2010b), the enhancement of the biodegradation rate was more obvious for high air flow rates as a result of improving the mass transfer inside the reactor by the combined effect of good mixing and reduced particle size. However, this is not significantly shown by the results in Fig. 3. This could be attributed to the fact that these experiments were carried out directly after acclimatization and it is suspected that there was a lot of loss in cells due to the cutting process, which still could not be compensated at the early stage of the process. This is depicted by the degradation by the $0.5 \mathrm{~cm}^{3}$ particles, which seemed to be the slowest in most of the runs.

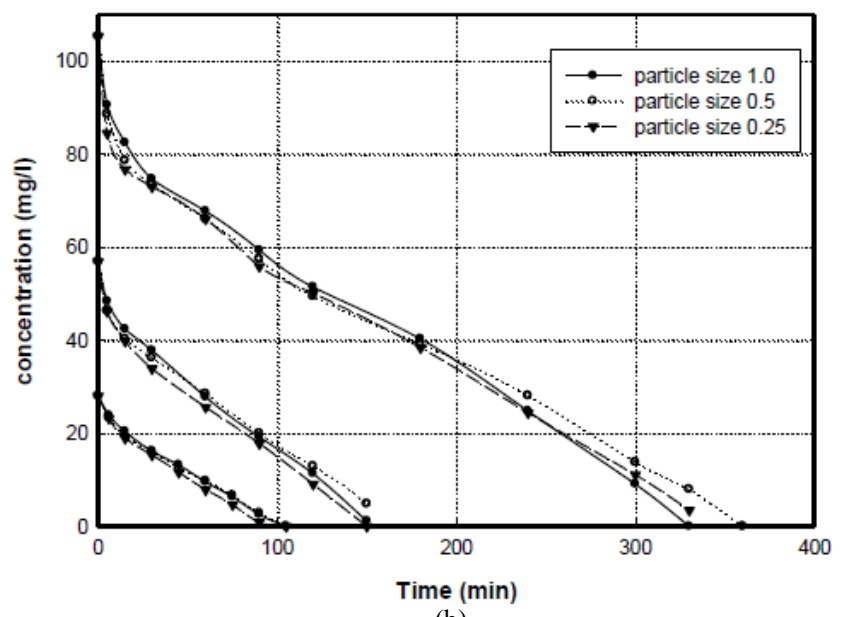

(b)

Fig. 2. Effect of PVA particle size at different initial DCP concentration; $\mathrm{T}=30^{\circ} \mathrm{C} ; \mathrm{pH}=8.2-8.4 ; \mathrm{AFR}=3 \mathrm{~L} \mathrm{~min}{ }^{-1}$ 


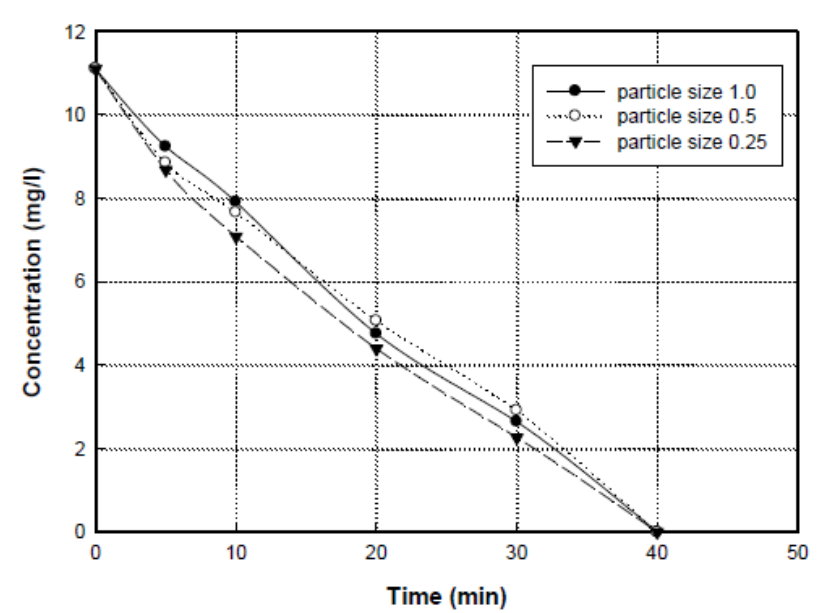

(a)

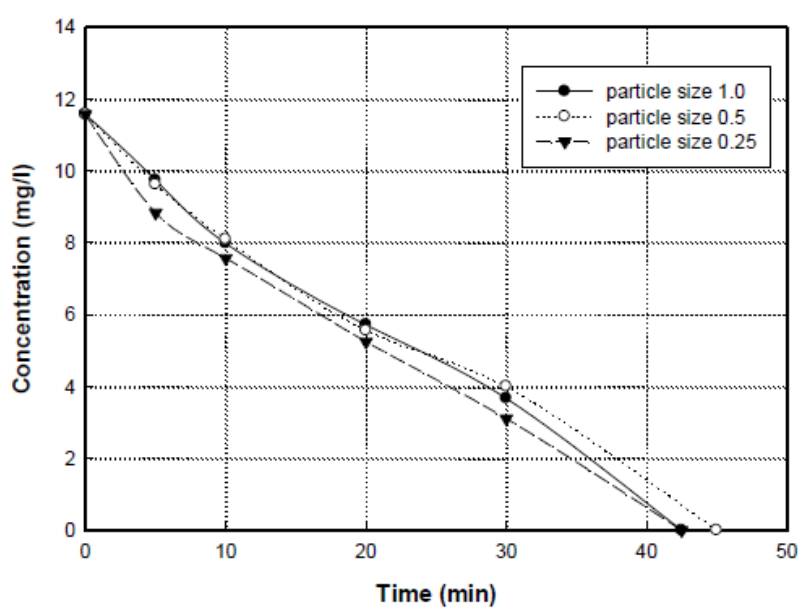

(b)

Fig. 3. Effect of PVA particle size at AFR of $1 \mathrm{~L} \mathrm{~min}^{-1}$ (a) and $5 \mathrm{~L} \mathrm{~min}^{-1}(\mathrm{~b}) ; \mathrm{T}=30^{\circ} \mathrm{C} ; \mathrm{pH}=8.2-8.4$

Based on the above and in view of the technical difficulty in using the $0.25 \mathrm{~cm}^{3}$ particles due to the attrition effect, it was decided to continue all subsequent experiments with P. putida immobilized in PVA gel particles of $1 \mathrm{~cm}^{3}$ in size (for simplicity, particle sizes in the figures will be designated as 1.0 , $0.5,0.25)$.

\section{Effect of Temperature}

The enzymatic activity and rate of metabolism are highly dependent on temperature, which makes it an important quantity in bioprocesses (Agarry et al., 2008b). Experiments were carried out to assess the effect of temperature in the range from $22^{\circ} \mathrm{C}$ (room temperature) to $40^{\circ} \mathrm{C}$ in two phases as shown in Fig. $4 \mathrm{a}$ and $4 \mathrm{~b}$. Figure $4 \mathrm{a}$ for the first phase indicates that the degradation rate increases with temperature up to $30^{\circ} \mathrm{C}$ and does not change at $35^{\circ} \mathrm{C}$. However, a strange phenomenon took place when the replicate run at $35^{\circ} \mathrm{C}$ was carried out, represented by the suppression of the degradation rate accompanied by the appearance of a peculiar peak in the GC chromatogram, which grew to a maximum before it started to diminish towards the end of the biodegradation time. It took the biomass about one week of daily operation to get rid of this incidental effect. Once the previous biodegradation ability was restored, the second phase of experimentation started to cover the whole temperature range. Since the biodegradation capacity changes due to biomass growth in PVA matrices, it was essential to conduct all the experiments for one factor sequentially within a short period of time. Thus all the experiments at the different temperatures were repeated as shown in Fig. 4b.

It is clear that the performance had even improved as represented by the shorter degradation times at all temperatures. The trend in Fig. $4 \mathrm{a}$ is reiterated by the increase in biodegradation rate with temperature to a maximum at $30^{\circ} \mathrm{C}$, which does not change much at $35^{\circ} \mathrm{C}$ (only one run at $35^{\circ} \mathrm{C}$ ). At $40^{\circ} \mathrm{C}$ the degradation rate decreased and again there was later a rather great suppression in the biodegradation rate, which was even more pronounced than the previous one and it is thought to be caused by the greater production of metabolites beyond $30^{\circ} \mathrm{C}$. According to a preliminary GC-MS identification, the likely possibility of the odd peak would be an aromatic material, dimethyl phthalate, or vitamin A aldehyde, which could be a bacterial enzyme released at those conditions. However, it has been pointed out by several studies (Chung et al., 2003; Lu et al., 1996; Reardon et al., 2000; Annadurai et al., 2002; Safont et al., 2012) that the formation of dead end metabolic intermediates or the toxic effect of the substrate on the cells is often associated with a yellowish to brownish colour change, often resulting from involving the meta-pathway for degradation, which is more related to incomplete mineralization (Solyanikova and Golovleva, 2004; Lu et al., 1996). Such a colour change has never been detected in any situation in the present study. Rigas et al. (2005) reported in their study on biodegradation of lindane that the chromatograms obtained by the GC showed no significant new peaks, which was considered an evidence for a biotransformation pathway proceeding with fast intermediate reaction rates and in favor of complete mineralization of the pollutant. It is believed that this topic of intermediate detection and characterization is worth further investigation.

El-Naas et al. (2009) believed that the key step in the biodegradation process, which is benzene ring cleavage, may be adversely affected by sudden exposure to temperatures higher than $35^{\circ} \mathrm{C}$. 


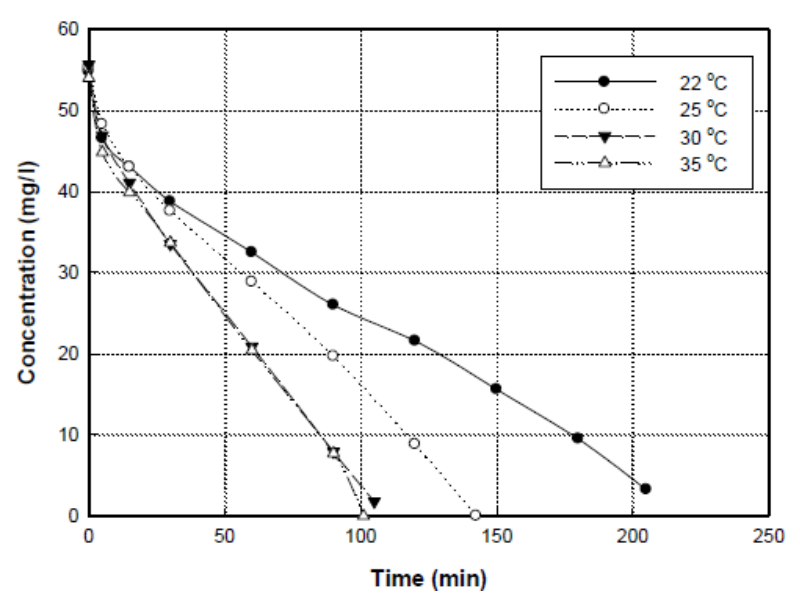

(a)

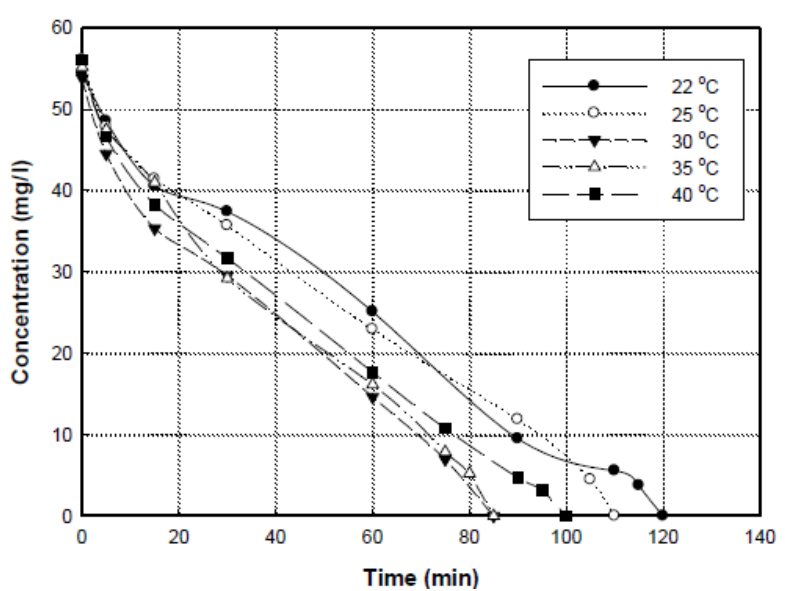

(b)

Fig. 4. Effect of temperature: experiments of phase 1 (a) and phase 2 (b); $\mathrm{C}_{\mathrm{o}}=55 \mathrm{mg} \mathrm{L}{ }^{-1} ; \mathrm{pH}=8.2-8.4 ; \mathrm{AFR}=3 \mathrm{~L} \mathrm{~min}^{-1}$

It is believed that the decrease in the reactivity of the enzyme system within the cell, that is usually responsible for ring cleavage, will result in a decrease in the degradation rate (Agarry et al., 2008b; Sheeja and Murugesan, 2002). Additionally, extreme temperatures lower the water solubility of oxygen resulting in insufficient content to favor a higher reaction rate at high temperatures (Menale et al., 2012). However, from Fig. 5, it can be seen that the highest degradation rate was at a temperature of $30^{\circ} \mathrm{C}$.

\section{Effect of Initial $\mathrm{pH}$}

The initial $\mathrm{pH}$ of the reaction medium is essentially considered a very important parameter in the development of biological processes owing to the critical role it plays in microbial growth and enzyme activity (Basak et al., 2013; Yao et al., 2009). The effect of the initial $\mathrm{pH}$ (from 5.0 to 10.0) on the DCP degradation rate was investigated. As shown in Fig. 6, at each initial $\mathrm{pH}$ of the reaction medium, the DCP could be completely utilized within less than $100 \mathrm{~min}$. However, the maximum degradation rate was perceived when the initial $\mathrm{pH}$ was 5.0 and the lowest when it was 10.0 , while the degradation times were very close in the range 7.0-9.0 of initial $\mathrm{pH}$. Therefore, the optimum $\mathrm{pH}$ value occurred at 5.0 in agreement with some other studies which utilized either enzymes or whole cells for DCP biodegradation (Menale et al., 2012). When following the $\mathrm{pH}$ value along the biodegradation process, it was noticed that the $\mathrm{pH}$ followed a similar trend to that of reduction of DCP concentration. This may be attributed to the organic acids formed as a consequence of intermediates formation during the degradation process. Sheeja and Murugesan (2002) reported that the $\mathrm{pH}$ will rise following the subsequent degradation of these acids; however, the final $\mathrm{pH}$ still remains less than the initial set value and this was evident in all the experiments of the current study.

The decrease in $\mathrm{pH}$ may be also due to $\mathrm{HCl}$ formation from the biodegradation of chlorophenols (Sahinkaya and Dilek, 2006). El-Naas et al. (2009) mentioned that the decrease in $\mathrm{pH}$ is caused by the production of $\mathrm{CO}_{2}$ that results in the formation of carbonic acid.

However, this decrease in $\mathrm{pH}$ value was confirmed in the cases where the initial $\mathrm{pH}$ was higher than 7.0. The greater the initial $\mathrm{pH}$ is, the greater the decrease in its value. On the contrary, when the initial $\mathrm{pH}$ was less than or equal to 7.0 , the $\mathrm{pH}$ increased during the reaction time. The lower the initial $\mathrm{pH}$ is, the higher the increase in its value. In both cases, the final $\mathrm{pH}$ would be in the range $6.5-8.0$, which is the optimum range of the used bacteria to thrive.

\section{Effect of Initial DCP Concentration}

In the biodegradation process, initial substrate concentration plays an important role, which is clearly recognized by the inhibitory effect of some hydrocarbon contaminants, including DCP, on the activity of the biomass. Experiments were carried out in the range of 25-200 $\mathrm{mg} \mathrm{L}^{-1}$ as shown in Fig. 7b, whereas Fig. 7a presents results from the previous group of experiments, which were performed during the study of particle size effect (for particle size 1.0). Complete degradation of DCP was observed at every initial concentration, which means that the inhibition effect was not significantly encountered, thanks to the protection provided to the bacteria within the PVA matrix by immobilization against the high contaminant concentration. It was noticed that DCP concentration decreased almost linearly with time and thus, the degradation rate may be assumed constant, following zero-order kinetics for all initial concentrations of DCP. A similar trend was observed by El-Naas et al. (2009) for the biodegradation of phenol. 


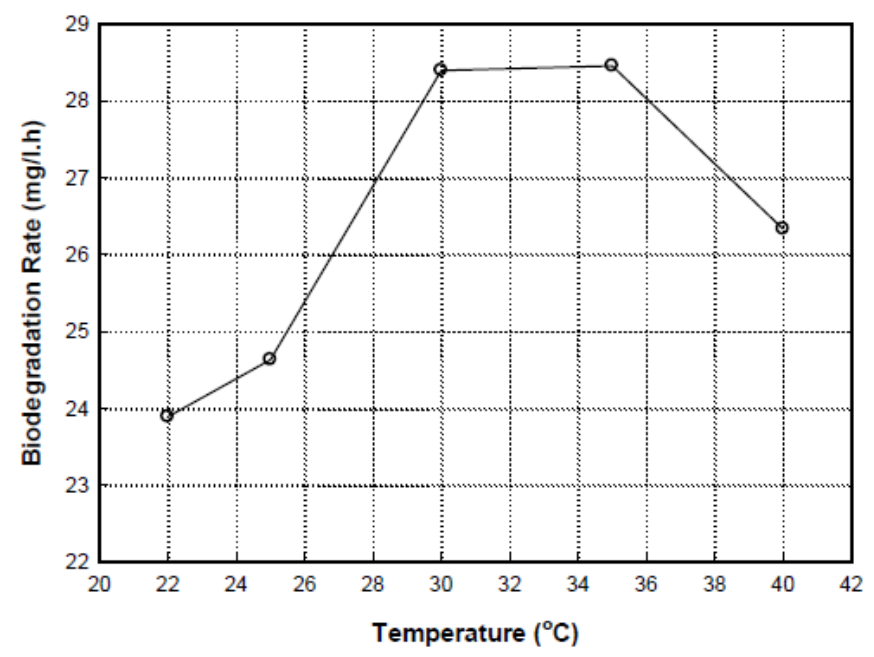

Fig. 5. Effect of temperature on DCP degradation rate

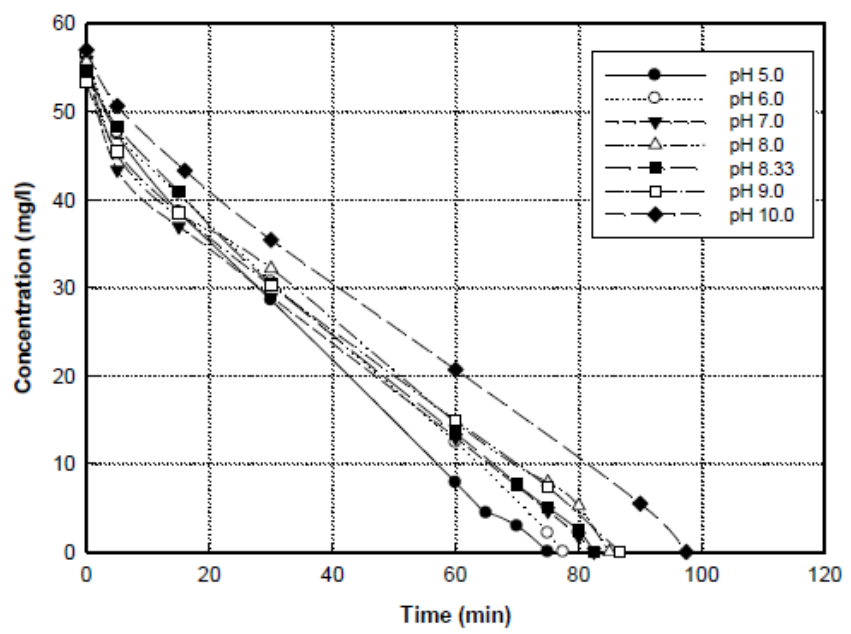

Fig. 6. Effect of initial $\mathrm{pH} ; \mathrm{T}=30^{\circ} \mathrm{C} ; \mathrm{C}_{\mathrm{o}}=55 \mathrm{mg} \mathrm{L}^{-1} ; \mathrm{AFR}=3 \mathrm{~L} \mathrm{~min}^{-1}$

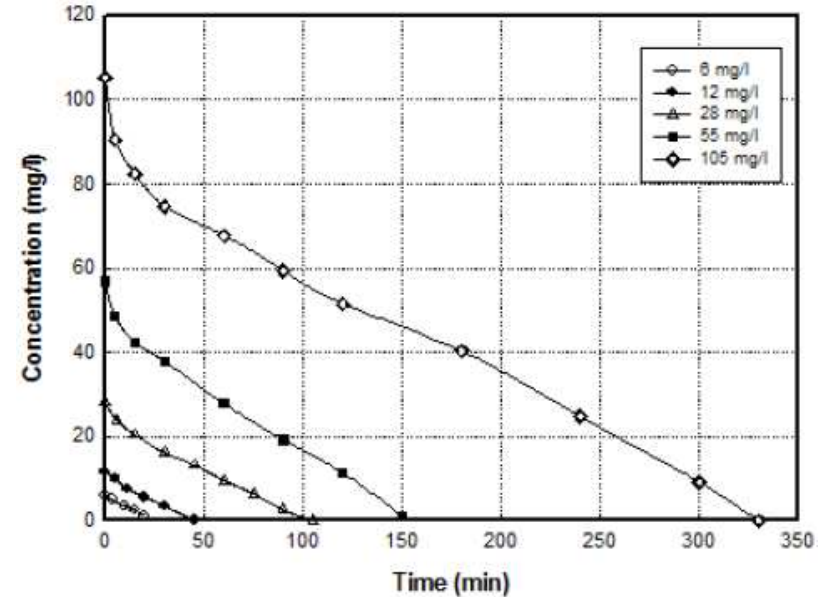

(a)

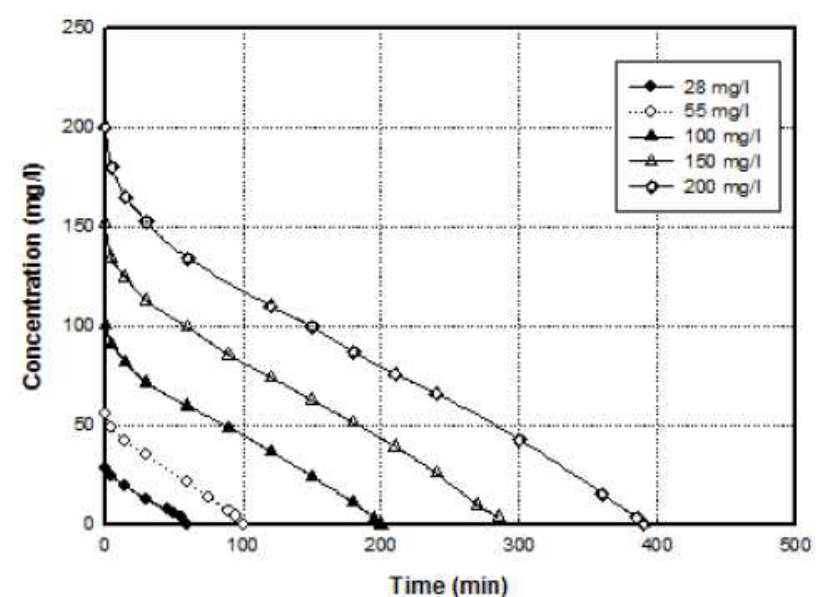

(b)

Fig. 7. Effect of initial DCP concentration: First set (a) and second set (b); $\mathrm{T}=30^{\circ} \mathrm{C} ; \mathrm{pH}=8.2-8.4 ; \mathrm{AFR}=3 \mathrm{~L} \mathrm{~min}^{-1}$ 


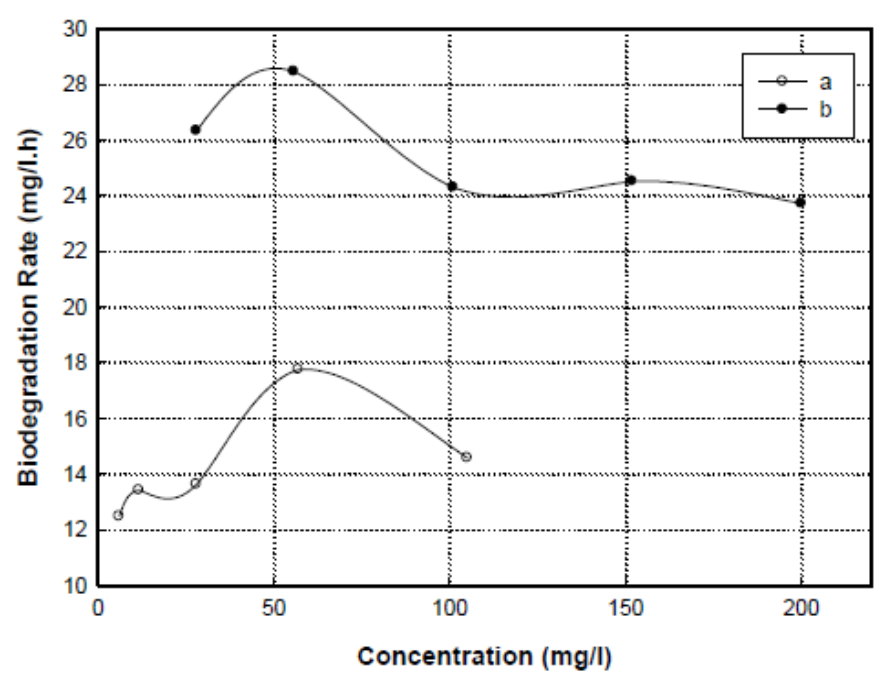

Fig. 8. Biodegradation rates for the data in Fig. 7

Biodegradation rates for the degradation data in Fig. $7 \mathrm{a}$ and $7 \mathrm{~b}$ are presented in Fig. 8 , referred to as (a) and (b), respectively. Both curves of the degradation rates reached a maximum at an initial substrate concentration of $55 \mathrm{mg} \mathrm{L}^{-1}$ and then decreased slightly and smoothly (b), which can be explained by a minor inhibitory effect toward the cells. On the other hand, the lower biodegradation rate at low DCP concentration could be attributed to mass transfer limitation, where there is less DCP accessible to the biomass. It is worth mentioning that the rates in the experiments of the more recent study (b) are superior to those of the previous study (a), which indicates the increase in the activity of the biomass as a result of cell growth over a time span of almost two months between the two studies.

This continued improvement in the performance of the biomass upon repeated use has been highlighted by others (Hsieh et al., 2008; El-Naas et al., 2013; Varma and Gaikwad, 2009; Ali et al., 2013). The biodegradation rates were calculated from the slopes of the best fitted straight line, ignoring the initial segment of fast drop in DCP concentration as it is thought to be much influenced by the dilution effect of water release from the PVA gel particles (water accounts for about $90 \%$ of the gel mass).

\section{Effect of Air Flow Rate in SBBR}

Air flow rate affects the biodegradation process in a SBBR through its direct relation with two main factors: Mixing and aeration (El-Naas et al., 2010b). To determine the effect of AFR, two groups of experiments were carried out at an initial concentration of $55 \mathrm{mg} \mathrm{L}^{-1}$ using different air flow rates: One group was conducted without adjustment of the initial $\mathrm{pH}$ (original $\mathrm{pH}$ of 8.3) as shown in Fig. 9a, whereas the other group was conducted with the initial $\mathrm{pH}$ adjusted to 5.0 as illustrated by Fig. 9b. Both figures show a trend of increase in the degradation rate with increase in AFR, being more pronounced at initial $\mathrm{pH}$ value of 5.0. This is mainly due to the reduction in external mass transfer resistance being induced by enhanced agitation and the increase in the amount of dissolved oxygen. In their study, El-Naas et al. (2010b) proved that at AFR higher than $1 \mathrm{~L} \mathrm{~min}^{-1}$, the main factor of enhancing continuous biodegradation of phenol in a SBBR at an initial concentration of $30 \mathrm{mg} \mathrm{L}^{-1}$ is the availability of sufficient oxygen rather than mixing, highlighting the importance of mixing effect in cases where PVA particles of smaller size are used or when the initial substrate concentration is very low. It was reported that high AFR may produce excessive foaming or air bubbles coalescence (Agarry et al., 2008b), which could adversely affect the biodegradation process but this effect was not observed in this study. However, to avoid these adverse effects at high AFR, which may also cause slugging and attrition of the PVA particles and to minimize the role of evaporation/stripping as well, it was decided to continue all the following experiments with AFR of $3.0 \mathrm{~L} \mathrm{~min}^{-1}$.

\section{Response Surface Methodology (RSM)}

The objective of applying the RSM is to determine the optimal operating conditions for the given process. The Box-Behnken design was employed to study the effects and interactions of the main parameters, namely temperature, $\mathrm{pH}$ and initial DCP concentration, to be further optimized for DCP biodegradation. The design was applied considering the three parameters at three levels. The experimental conditions and the corresponding results obtained, expressed as global biodegradation rates are summarized in Table 3. 


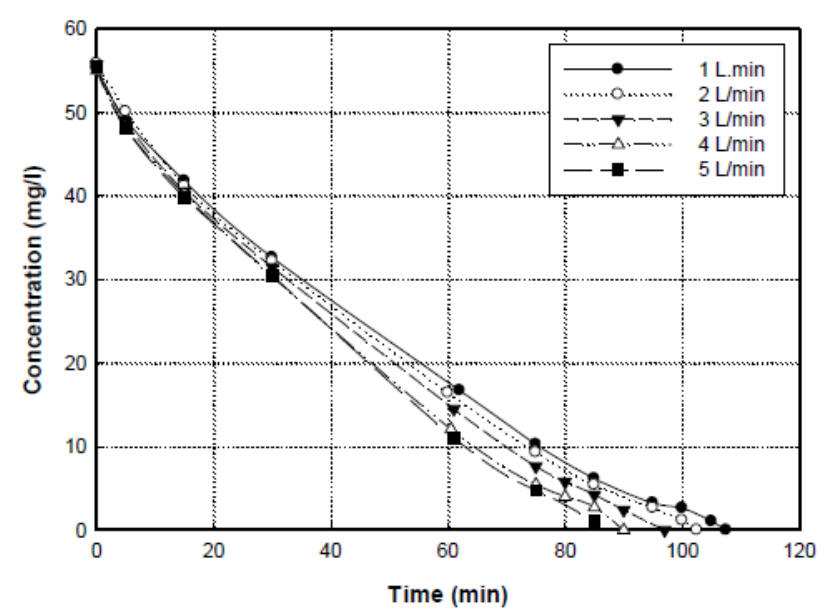

(a)

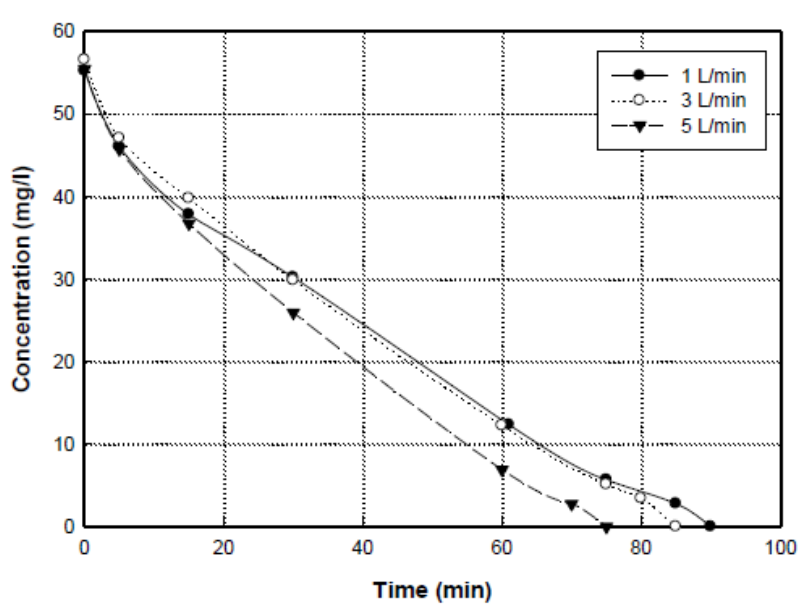

(b)

Fig. 9. Effect of inlet air flow rate at initial $\mathrm{pH} 8.3$ (a) and 5.0 (b); $\mathrm{T}=30^{\circ} \mathrm{C} ; \mathrm{C}_{\mathrm{o}}=55 \mathrm{mg} \mathrm{L}{ }^{-1}$

Table 3. The Box-Behnken experimental design along with the actual and predicted responses

\begin{tabular}{|c|c|c|c|c|c|}
\hline \multirow[b]{2}{*}{ Run order } & \multirow[b]{2}{*}{$\mathrm{A}(\mathrm{T})$} & \multirow[b]{2}{*}{$\mathrm{B}(\mathrm{pH})$} & \multirow[b]{2}{*}{$\mathrm{C}\left(\mathrm{C}_{\mathrm{o}}\right)$} & \multicolumn{2}{|c|}{ Global degradation rate, $\mathrm{mg} \mathrm{L}^{-1} \mathrm{~h}^{-1}$} \\
\hline & & & & Experimental & Predicted \\
\hline 1 & 0 & 1 & 1 & 34.85 & 33.30 \\
\hline 2 & -1 & 0 & 1 & 28.41 & 29.47 \\
\hline 3 & 1 & -1 & 0 & 41.71 & 41.22 \\
\hline 4 & 0 & 0 & 0 & 37.02 & 37.69 \\
\hline 5 & -1 & 1 & 0 & 29.70 & 30.19 \\
\hline 6 & 1 & 1 & 0 & 34.74 & 34.86 \\
\hline 7 & 1 & 0 & 1 & 33.07 & 34.50 \\
\hline 8 & 0 & 1 & -1 & 27.24 & 28.18 \\
\hline 9 & 0 & 0 & 0 & 37.70 & 37.69 \\
\hline 10 & 0 & 0 & 0 & 38.35 & 37.69 \\
\hline 11 & 0 & -1 & 1 & 37.16 & 36.22 \\
\hline 12 & -1 & -1 & 0 & 36.40 & 36.28 \\
\hline 13 & -1 & 0 & -1 & 29.30 & 27.87 \\
\hline 14 & 1 & 0 & -1 & 33.52 & 32.46 \\
\hline 15 & 0 & -1 & -1 & 36.15 & 37.70 \\
\hline
\end{tabular}

\section{Regression Model}

The experimental data were subjected to multiple regression analysis to fit a second order polynomial regression model containing 3 linear, 3 quadratic and 3 interaction terms. Hence, the following second order polynomial equation was obtained to represent the global rate of DCP degradation adequately. The mathematical formulation is given below in terms of coded factors:

$$
\begin{aligned}
& Y=37.69+2.40 A-3.11 B+0.91 C-2.41 A^{2} \\
& +0.36 B^{2}-0.42 C^{2}-0.07 A B+0.11 A C+1,65 B C
\end{aligned}
$$

and in terms of uncoded factors:

$$
\begin{aligned}
& Y=-50.90+6.29 T-3.86 p H+0.14 C_{o} \\
& -0.1 T^{2}+0.09 p H^{2}-0.002 C_{o}{ }^{2} \\
& -0.01 T p H+0.0004 T C_{o}+0.017 p H C_{o}
\end{aligned}
$$

Where:

$A=$ The temperature $\left({ }^{\circ} \mathrm{C}\right)$

$B=$ The initial $\mathrm{pH}$ value

$C=$ The initial DCP concentration $\left(\mathrm{mg} \mathrm{L}^{-1}\right)$

$Y=$ The response represented by the global degradation rate of DCP $\left.\left(\mathrm{mg} \mathrm{L}^{-1} \mathrm{~h}^{-1}\right)\right)$

$A, B, C$ are the independent factors in the BoxBehnken design. Positive values of $A$ and $C$ in Equation 1 indicated that DCP degradation rate increased as temperature and initial DCP concentration increased, whereas it increased as $\mathrm{pH}$ decreased. This was reflected by the negative coefficient of $\mathrm{B}$. The trends for the first-order terms were as expected as they were matching the effects derived from the experimental data.

It is essential to analyze the statistical significance of the regression model of 2, 4 DCP biodegradation to assess its reliability in representing the data. So, the 
Analysis Of Variance (ANOVA) of the quadratic equation was performed as presented in Table 4. The coefficients of the regression model as represented by Equation 1 are listed in Table 5.

A $p$-value below 0.05 for any regression coefficient indicates that it is statistically significant. Thus, the model may be assumed highly significant based on a low failure probability $(p=0.014)$ and a coefficient of determination $\left(R^{2}\right)$ value of 0.9403 , as well as a value of the adjusted $R^{2}$ of 0.8328 . These values confirm the adequacy of the model, with the indication that $94.03 \%$ of the total variations in the response could be explained by the model. Moreover, the $p$-value of 0.091 for the lack-of-fit of the model indicates that it is insignificant at the $95 \%$ confidence level, in support for the adequacy of the model to represent the experimental results.

The coefficients listed in Table 5 are three linear, three quadratic, three interaction terms and one block term. Also listed in Table 5 are the corresponding Student's $t$-test and $p$-values, which serve as a measure to determine the significance of each coefficient; the greater the $t$-value and smaller the $p$-value, the more significant is the corresponding coefficient. Accordingly, it is found out that the first order main effects of A (temperature) and $\mathrm{B}$ $(\mathrm{pH})$ and the second order effects of $\mathrm{A}$ and $\mathrm{C}$ (initial DCP concentration) are highly significant as implied by their respective $p$-values $<0.05$. The quadratic effect of $\mathrm{C}$ was more pronounced than its linear effect. All the interaction effects had $p$-values $>0.05$, making them insignificant. This has the implication that some parameters under study for the biodegradation of 2, 4 DCP are not highly affected by each other.

The normal probability and parity plots further verified the model adequacy, as depicted in Fig. 10 and 11 , respectively. The residuals analysis reveals that there were no outliers as all the standardized residuals fell within the range of -2 to +2 , being also randomly distributed around zero. This is an evidence of a high degree of correlation between the observed values and predicted values. This was also demonstrated by the parity plot, with the points clustering very closely around the diagonal line confirming the little discrepancy between the observed and predicted values (as obtained from Equation 1) for rate of DCP degradation.

Table 4. Analysis of Variance (ANOVA) for the regression model

\begin{tabular}{llcrl}
\hline Source & Degree of freedom & Sum of squares & Adjusted sum of squares & $p$-value \\
\hline Model & 9 & 225.244 & 225.244 & 0.014 \\
Linear & 3 & 130.288 & 130.288 & 0.006 \\
$\mathrm{~A}$ & 1 & 46.224 & 46.224 & 0.010 \\
$\mathrm{~B}$ & 1 & 77.439 & 77.439 & 0.003 \\
$\mathrm{C}$ & 1 & 6.625 & 6.625 & 0.189 \\
Square & 3 & 84.000 & 84.000 & 0.016 \\
$\mathrm{~A}^{2}$ & 1 & 17.089 & 21.512 & 0.041 \\
$\mathrm{~B}^{2}$ & 1 & 1.740 & 0.482 & 0.699 \\
$\mathrm{C}^{2}$ & 1 & 65.171 & 65.171 & 0.005 \\
Interaction & 3 & 10.957 & 10.957 & 0.378 \\
$\mathrm{~A}^{*} \mathrm{~B}$ & 1 & 0.018 & 0.018 & 0.939 \\
$\mathrm{~A}^{*} \mathrm{C}$ & 1 & 0.048 & 0.048 & 0.902 \\
$\mathrm{~B}^{*} \mathrm{C}$ & 1 & 10.890 & 10.890 & 0.109 \\
Residual rror & 5 & 14.305 & 14.305 & 0.091 \\
Lack-of-fit & 3 & 13.342 & 13.421 & 0.885 \\
Pure error & 2 & 0.885 & & 0.09 \\
Total & 14 & 239.549 & & \\
$\mathrm{R}^{2}=94.03 \%$ & & Adjusted $\mathrm{R}^{2}=83.28 \%$ & & \\
\hline
\end{tabular}

Table 5. Coefficients for the quadratic regression model

\begin{tabular}{lllll}
\hline Term & Value & Standard error & $t$-value & $p$-value \\
\hline Constant & 37.69 & 0.9766 & 38.594 & 0.000 \\
Temp: A & 2.4038 & 0.5980 & 4.019 & 0.010 \\
pH: B & -3.1113 & 0.5980 & -5.203 & 0.003 \\
DCP Conc: C & 0.9100 & 0.5980 & 1.522 & 0.189 \\
Temp*Temp: A & -2.4137 & 0.8803 & -2.742 & 0.041 \\
pH*pH: B & 0.3612 & 0.8803 & 0.410 & 0.699 \\
DCP conc*DCP conc: C & -4.2013 & 0.8803 & -4.773 & 0.005 \\
Temp*pH: AB & -0.0675 & 0.8457 & -0.080 & 0.939 \\
Temp*DCP conc: AC & 0.1100 & 0.8457 & 0.130 & 0.902 \\
pH*DCP conc: BC & 1.6500 & 0.8457 & 1.951 & 0.109 \\
\hline
\end{tabular}




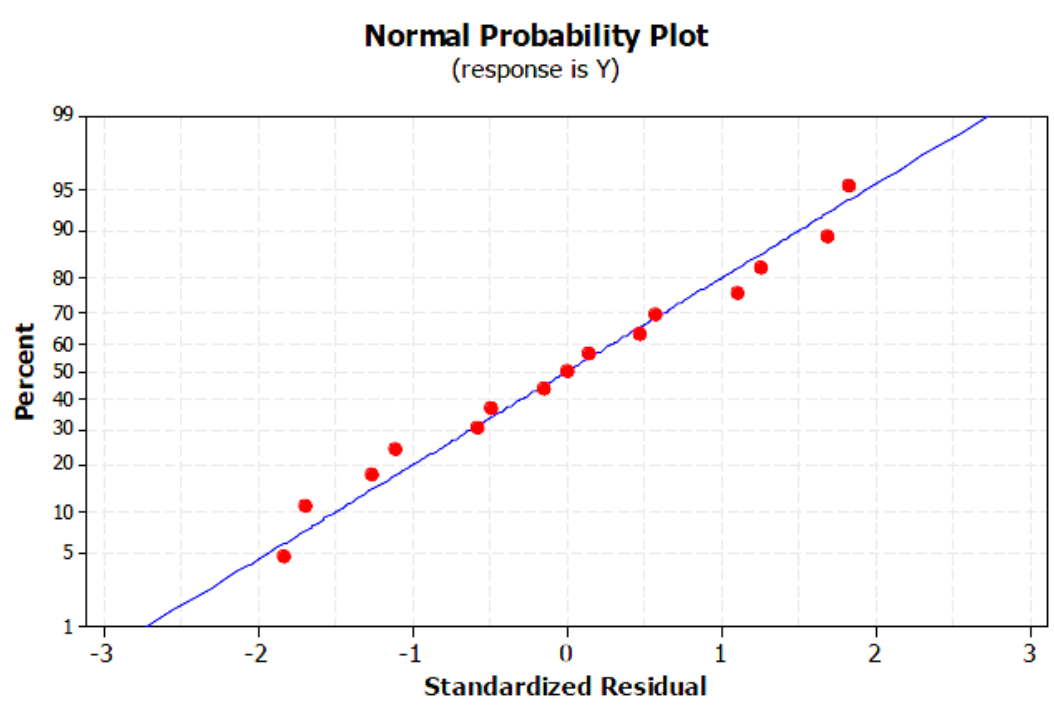

Fig. 10. Normal probability plot of standardized residuals

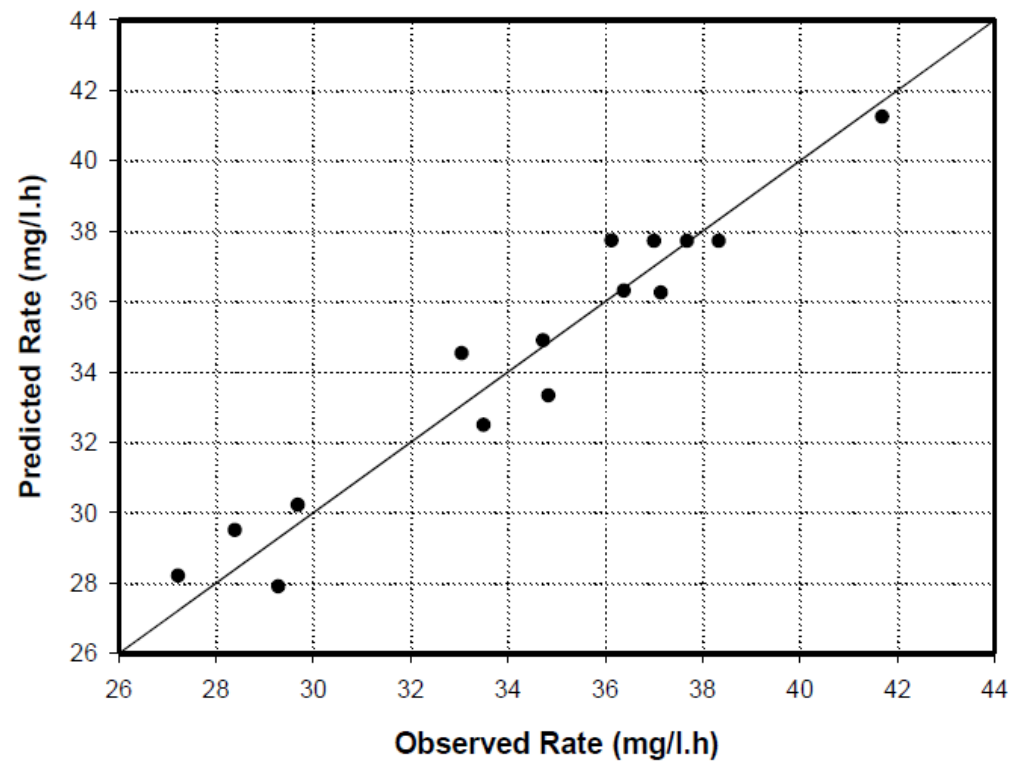

Fig. 11. Parity plot: Predicted versus observed rate

\section{Model Optimization for Maximum Degradation Rate}

Model optimization targets the identification of the optimum conditions for maximum degradation rate. The contour plots and their respective three-dimensional surface plots provide a visual explanation of the interaction between two variables and help in locating optimum experimental conditions (Wu et al., 2009). Figure 12 and 13 represent the contour and surface plots, respectively, for the optimization of DCP degradation. The mutual interactions between the variables are depicted by the shapes of the contour plots, tending to an elliptical shape for a significant interaction between variables (Wu et al., 2009;
Agarry et al., 2008b). Also, the more the curvature in the surface plots, the more significant the interaction. This is depicted by the elliptical shape of the contour plots and their respective curved surface plots of the mutual interactions $\mathrm{AB}, \mathrm{AC}$ and $\mathrm{BC}$. Figure 12 and 13 suggest the location of the optimum range of the process variables. Using response optimizer by Minitab, the stationary point of maximum aerobic biodegradation rate inside the experimentation region had the following critical values: Temperature $32.58^{\circ} \mathrm{C}$ (0.5152), pH $5.0(-1)$ and initial DCP concentration was $70.46 \mathrm{mg} \mathrm{L}^{-1}(-0.0909)$. Under these conditions, the predicted maximum aerobic global biodegradation rate was $41.82 \mathrm{mg} \mathrm{L}^{-1} \mathrm{~h}^{-1}$. 


\section{Validation of the Model}

Model validation is an important step to consider a model practically reliable and fit, so as to ensure that the predicted responses reasonably match the results obtained in the field (Bhattacharya et al., 2009). The suitability of the model, as represented by Equation 1 and 2, was tested by performing batch biodegradation experiments at the predicted optimum conditions. Also, other selected conditions were tested to compare the experimental degradation rates with those predicted by the model. The validation experiments were replicated. Table 6 summarizes the results on experimental and predicted responses at the $95 \%$ confidence interval. It shows the closeness of the model-predicted responses to the experimental results, confirming the model reliability for predicting the aerobic biodegradation of DCP by $P$. putida. Recalling the results on temperature effect, the observation was that on carrying out the replicate run at $35^{\circ} \mathrm{C}$ there was a suppression of the degradation rate accompanied by the appearance of a peculiar peak in the chromatogram: It is noteworthy that the bacterial activity was found to be at risk even at a temperature of $33^{\circ} \mathrm{C}$. Replicated rates at this temperature could be achieved only when the suppression effect had been reduced.

Thus, although the RSM predicted an optimum operating temperature of $32.5^{\circ} \mathrm{C}$, the sustainability of the bacterial activity is doubtful at this temperature. Bioprocesses are rather sensitive in terms of achieving reproducibility, which imposes some limitations on the applicability of the model.

\section{Contour Plots of Rate}
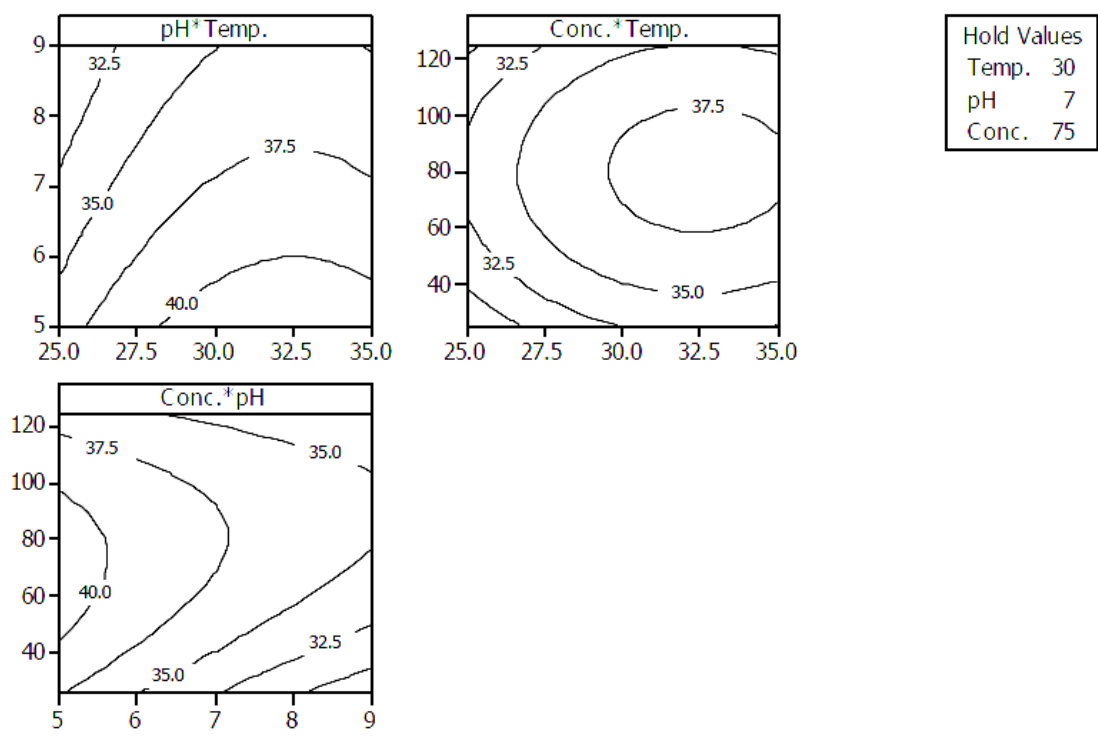

Fig. 12. Contour plots of response versus the different interactions of independent variables

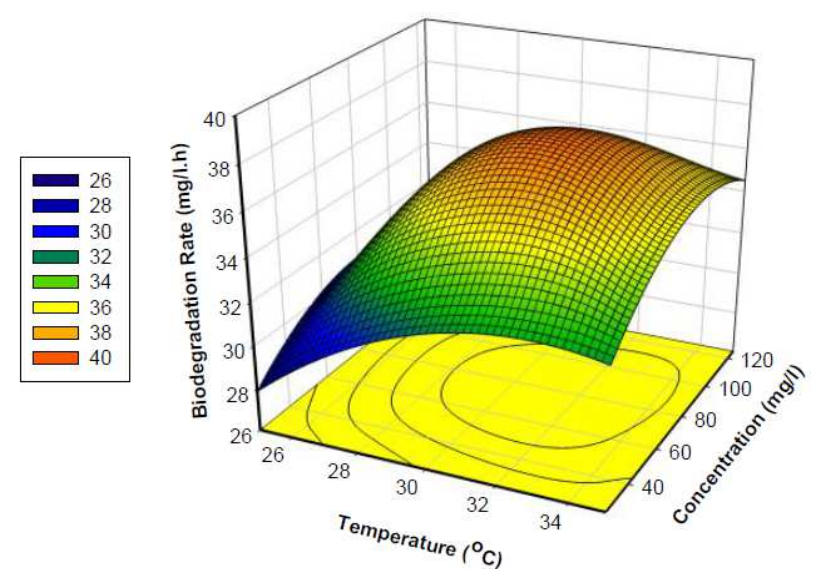

(a)

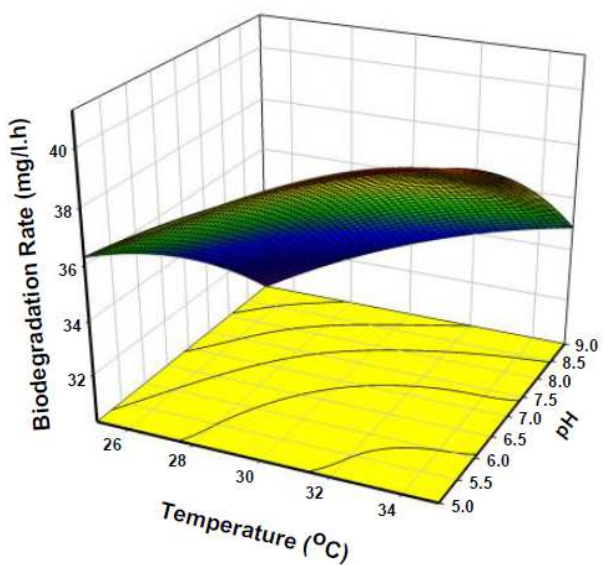

(b) 


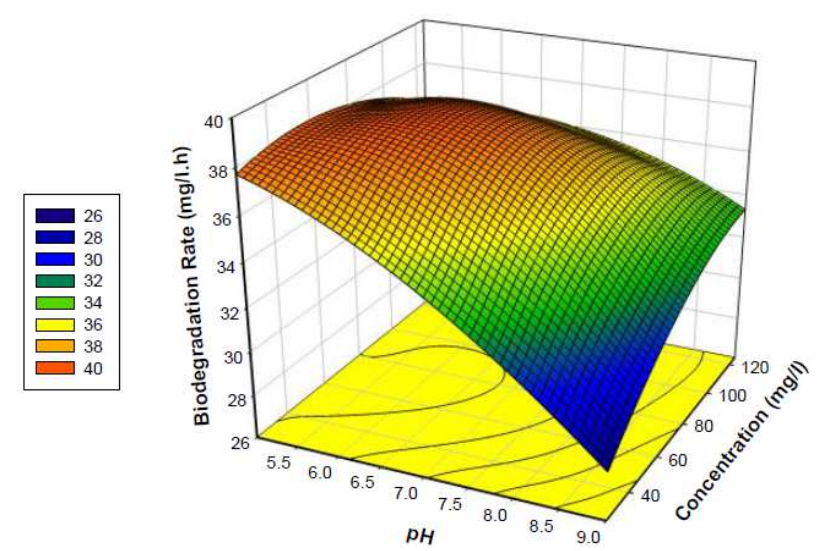

(c)

Fig. 13. Response surface plots of response versus the different interactions of independent variables ( $\mathrm{pH}$, initial concentration and temperature were held constant at their respective center levels in (a), (b) and (c), respectively)

Table 6. Validation of the RSM regression model

\begin{tabular}{llllll}
\hline $\mathrm{T},{ }^{\circ} \mathrm{C}$ & Initial $\mathrm{pH}$ & $\mathrm{C}_{\mathrm{o}}, \mathrm{mg} / \mathrm{l}$ & Observed rate, $\mathrm{mg} / \mathrm{l} . \mathrm{h}$ & Predicted rate, $\mathrm{mg} / \mathrm{l} . \mathrm{h}$ & $95 \%$ Confidence interval \\
\hline 30 & 9.0 & 53.67 & 35.38 & 33.08 & $30.27 ; 35.90$ \\
30 & 8.4 & 28 & 27.67 & 30.06 & $27.12 ; 32.95$ \\
32.5 & 5.0 & 71.17 & 40.05 & $41.82 *$ & $38.96 ; 44.69$ \\
27 & 6.0 & 81.18 & 33.91 & 36.94 & $34.63 ; 39.26$ \\
27 & 6.0 & 41 & 31.96 & 34.93 & $32.57 ; 37.55$ \\
30 & 8.3 & 55.17 & 34.37 & 34.39 & $32.04 ; 36.70$ \\
30 & 5.0 & 54.37 & 42.87 & 40.75 & $37.94 ; 43.56$ \\
30 & 5.0 & 75 & 39.4 & 41.16 & $38.43 ; 43.90$ \\
\hline
\end{tabular}

*Degradation rate at the optimum conditions

\section{Conclusion}

The present study showed the effective degradation of 2, $4 \mathrm{DCP}$, up to $200 \mathrm{mg} \mathrm{L}^{-1}$, by a special consortium of $P$. putida immobilized in PVA gel structure, using a spouted bed bioreactor. Planned design of experiments by response surface methodology with a Box-Behnken design, coupled with the classical single-parameter selection technique, was successfully applied to identify the optimal conditions for 2, 4 DCP removal based on the degradation rates obtained from batch experiments. The key process parameters were identified and their effects were evaluated, along with the interactions amongst the different variables. A true functional relationship, based on a quadratic model, between the dependent variable, which is the response expressed as a global degradation rate of 2, 4 DCP and the main independent variables, namely temperature, initial $\mathrm{pH}$ and initial concentration of 2, 4 DCP has been developed.

The model showed a good fit with $R^{2}$ and adjusted $R^{2} 94.03$ and $83.28 \%$, respectively, which indicates a reasonably adequate model for practical application. The optimum conditions for 2, 4 DCP biodegradation by $P$. putida were as follows: PVA particle size of 1 $\mathrm{cm}^{3}$ and inlet air flow rate of $3 \mathrm{~L} \mathrm{~min}^{-1}$, as determined from the single-factor experiments; temperature 32.58
${ }^{\circ} \mathrm{C}$, pH 5.0 and initial DCP concentration $70.46 \mathrm{mg}$ $\mathrm{L}^{-1}$, as determined by the regression model; resulting in a maximum predicted degradation rate of $41.82 \mathrm{mg}$ $\mathrm{L}^{-1} \mathrm{~h}^{-1}$. These optimized conditions, as well as other conditions, were further experimentally validated and a degradation rate of $40.05 \mathrm{mg} \mathrm{L}^{-1} \mathrm{~h}^{-1}$ was obtained at the optimized conditions. Hence, the model prediction is confirmed to be close to the experimental results. By this model, the response for the key factors can be predicted at any time. The optimum operating conditions obtained give a basis for further study with continuous-mode operation for the degradation of DCP in industrial wastewater.

\section{Acknowledgement}

The authors would like to acknowledge the financial support provided by the United Arab Emirates University as part of the PhD Scholarship Program.

\section{Author's Contributions}

Taghreed Al-Khalid: She made considerable contributions including carrying out the experimental work, analyzing and modeling the experimental data. She also prepared the initial draft of the manuscript. 
Muftah El-Naas: He made considerable contributions including designing the research plan and experimental procedure. In addition, he supervised the experimental work and revised the draft of the manuscript.

\section{Ethics}

This paper is original and includes unpublished materials. The corresponding author authorizes that the other author has read and approved the manuscript and there is no ethical issues involved.

\section{References}

Agarry, S.E., A.O. Durojaiye and B.O. Solomon, 2008a. Microbial degradation of phenols: A review. Int. J. Environ. Pollut., 32: 12-28. DOI: 10.1504/ijep.2008.016895

Agarry, S.E., B.O. Solomon and S.K. Layokun, 2008b. Optimization of process variables for the microbial degradation of phenol by Pseudomonas aeruginosa using response surface methodology. African J. Biotechnol., 7: 2409-2416. DOI: 10.5897/ajb07.220

Al Zarooni, M. and W. Elshorbagy, 2006. Characterization and assessment of Al Ruwais refinery wastewater. J. Hazardous Mater., 136: 398-405. DOI: 10.1016/j.jhazmat.2005.09.060

Al-Khalid, T.T. and M.H. El-Naas, 2012. Aerobic biodegradation of phenols: A comprehensive review. Critical Rev. Environ. Sci. Technol., 42: 1631-1690. DOI: 10.1080/10643389.2011.569872

Ali, O., A. Namane and A. Hellal, 2013. Use and recycling of $\mathrm{Ca}$-alginate biocatalyst for removal of phenol from wastewater. J. Industr. Eng. Chem., 19: 1384-1390. DOI: 10.1016/j.jiec.2012.12.045

Angelini, V.A., J. Orejas, M.I. Medina and E. Agostini, 2011. Scale up of 2,4-dichlorophenol removal from aqueous solutions using Brassica napus hairy roots. J. Hazardous Mater., 185: 269-274. DOI: $10.1016 /$ j.jhazmat.2010.09.028

Annadurai, G., R.S. Juang and D.J. Lee, 2002. Microbiological degradation of phenol using mixed liquors of Pseudomonas putida and activated sludge. Waste Manage., 22: 703-710. DOI: $10.1016 / \mathrm{S} 0956-053 \mathrm{X}(02) 00050-8$

Annadurai, G., L.Y. Ling and J.F. Lee, 2008. Statistical optimization of medium components and growth conditions by response surface methodology to enhance phenol degradation by Pseudomonas putida. J. Hazardous Mater., 151: 171-178. DOI: 10.1016/j.jhazmat.2007.05.061

Bajaj, M., C. Gallert and J. Winter, 2008. Biodegradation of high phenol containing synthetic wastewater by an aerobic fixed bed reactor. Bioresource Technol., 99: 8376-8381. DOI: 10.1016/j.biortech.2008.02.057
Bapat, P.S., P.R. Gogate and A.B. Pandit, 2008. Theoretical analysis of sonochemical degradation of phenol and its chloro-derivatives. Ultrasonics Sonochem., 15: 564-570. DOI: 10.1016/j.ultsonch.2007.08.002

Basak, B., B. Bhunia, S. Dutta and A. Dey, 2013. Enhanced biodegradation of 4-chlorophenol by Candida tropicalis PHB5 via optimization of physicochemical parameters using Taguchi orthogonal array approach. Int. Biodeteriorat. Biodegradat., 78: 17-23.

DOI: 10.1016/j.ibiod.2012.12.005

Bhattacharya, S.S. and R. Banerjee, 2008. Laccase mediated biodegradation of 2,4-dichlorophenol using response surface methodology. Chemosphere, 73: 81-85.

DOI: 10.1016/j.chemosphere.2008.05.005

Bhattacharya, S.S., S. Karmakar and R. Banerjee, 2009. Optimization of laccase mediated biodegradation of 2,4-dichlorophenol using genetic algorithm. Water Res., 43: 3503-3510. DOI: $10.1016 /$ j.watres.2009.05.012

Chung, T.P., H.Y. Tseng and R.S. Juang, 2003. Mass transfer effect and intermediate detection for phenol degradation in immobilized Pseudomonas putida systems. Process Biochem., 38: 1497-1507. DOI: $10.1016 / \mathrm{S} 0032-9592(03) 00038-4$

Cutright, T.J. and L. Meza, 2007. Evaluation of the aerobic biodegradation of trichloroethylene via response surface methodology. Environ. Int., 33: 338-345. DOI: 10.1016/j.envint.2006.11.012

El-Naas, M.H., S.A. Al-Muhtaseb and S. Makhlouf, 2009. Biodegradation of phenol by Pseudomonas putida immobilized in Polyvinyl Alcohol (PVA) gel. J. Hazardous Mater., 164: 720-725. DOI: $10.1016 /$ j.jhazmat.2008.08.059

El-Naas, M.H., S. Al-Zuhair and S. Makhlouf, 2010a. Batch degradation of phenol in a spouted bed bioreactor system. J. Industr. Eng. Chem., 16: 267-272. DOI: 10.1016/j.jiec.2009.09.072

El-Naas, M.H., S. Al-Zuhair and S. Makhlouf, $2010 \mathrm{~b}$. Continuous biodegradation of phenol in a spouted bed bioreactor (SBBR). Chem. Eng. J., 160: 565-570. DOI: 10.1016/j.cej.2010.03.068

El-Naas, M.H., A.H.I. Mourad and R. Surkatti, 2013. Evaluation of the characteristics of Polyvinyl Alcohol (PVA) as matrices for the immobilization of Pseudomonas putida. Int. Biodeteriorat. Biodegradat., 85: 413-420. DOI: 10.1016/j.ibiod.2013.09.006

Farrell, A. and B. Quilty, 2002. The enhancement of 2chlorophenol degradation by a mixed microbial community when augmented with Pseudomonas putida CP1. Water Res., 36: 2443-2450. DOI: $10.1016 / \mathrm{S} 0043-1354(01) 00481-\mathrm{X}$ 
Hsieh, F.M., C. Huang, T.F. Lin, Y.M. Chen and J.C. Lin, 2008. Study of sodium tripolyphosphatecrosslinked chitosan beads entrapped with Pseudomonas putida for phenol degradation. Process Biochem., 43: 83-92. DOI: $10.1016 /$ j.procbio.2007.10.016

Kargi, F. and S. Eker, 2005. Removal of 2,4dichlorophenol and toxicity from synthetic wastewater in a rotating perforated tube biofilm reactor. Process Biochem., 40: 2105-2111.

DOI: $10.1016 /$ j.procbio.2004.07.013

Khan, M.Z., P.K. Mondal and S. Sabir, 2011. Bioremediation of 2-chlorophenol containing wastewater by aerobic granules-kinetics and toxicity. J. Hazardous Mater., 190: 222-228. DOI: $10.1016 /$ j.jhazmat.2011.03.029

Kılıç, N.K., 2009. Enhancement of phenol biodegradation by Ochrobactrum sp. isolated from industrial wastewaters. Int. Biodeteriorat. Biodegradat., 63: 778-781. DOI: 10.1016/j.ibiod.2009.06.006

Kusic, H., N. Koprivanac and A.L. Bozic, 2011. Treatment of chlorophenols in water matrix by UV/ferrioxalate system: Part I. Key process parameter evaluation by response surface methodology. Desalination, 279: 258-268. DOI: 10.1016/j.desal.2011.06.017

Liu, Y.J., A.N. Zhang and X.C. Wang, 2009. Biodegradation of phenol by using free and immobilized cells of Acinetobacter sp. XA05 and Sphingomonas sp. FG03. Biochem. Eng. J., 44: 187-192. DOI: 10.1016/j.bej.2008.12.001

Lu, C.J., C.M. Lee and C.Z. Huang, 1996. Biodegradation of chlorophenols by immobilized pure-culture microorganisms. Water Sci. Technol., 34: 67-72.

DOI: 10.1016/S0273-1223(96)00698-1

Majumder, P.S. and S.K. Gupta, 2007. Removal of chlorophenols in sequential anaerobic-aerobic reactors. Bioresource Technol., 98: 118-129.

DOI: 10.1016/j.biortech.2005.11.009

Menale, C., C. Nicolucci, M. Catapane, S. Rossi and U. Bencivenga et al., 2012. Optimization of operational conditions for biodegradation of chlorophenols by laccase-polyacrilonitrile beads system. J. Molecular Catalysis B: Enzymatic, 78: 38-44. DOI: 10.1016/j.molcatb.2012.01.021

Nair, C.I., K. Jayachandran and S. Shashidhar, 2008. Biodegradation of phenol. African J. Biotechnol. 7: 4951-4958. DOI: 10.5897/AJB08.087

Olaniran, A.O. and E.O. Igbinosa, 2011. Chlorophenols and other related derivatives of environmental concern: Properties, distribution and microbial degradation processes. Chemosphere, 83: 1297-1306.

DOI: 10.1016/j.chemosphere.2011.04.009
Papazi, A. and K. Kotzabasis, 2007. Bioenergetic strategy of microalgae for the biodegradation of phenolic compounds-Exogenously supplied energy and carbon sources adjust the level of biodegradation. J. Biotechnol., 129: 706-716. DOI: 10.1016/j.jbiotec.2007.02.021

Reardon, K.F., D.C. Mosteller and J.D. Rogers, 2000. Biodegradation kinetics of benzene, toluene and phenol as single and mixed substrates for Pseudomonas putida F1. Biotechnol. Bioeng., 69: 385-400. DOI: 10.1002/10970290(20000820)69:4<385::aid-bit5>3.0.co;2-q

Rigas, F., V. Dritsa, R. Marchant, K. Papadopoulou and E.J. Avramides et al., 2005. Biodegradation of lindane by Pleurotus ostreatus via central composite design. Environ. Int., 31: 191-196. DOI: 10.1016/j.envint.2004.09.024

Safont, B., A.I. Vitas and F.J. Peñas, 2012. Isolation and characterization of phenol degrading bacteria immobilized onto cyclodextrin-hydrogel particles within a draft tube spouted bed bioreactor. Biochem. Eng. J., 64: 69-75. DOI: 10.1016/j.bej.2012.03.005

Sahinkaya, E. and F.B. Dilek, 2006. Effect of biogenic substrate concentration on the performance of sequencing batch reactor treating 4-CP and 2,4-DCP mixtures. J. Hazardous Mater., 128: 258-264.

DOI: 10.1016/j.jhazmat.2005.08.002

Sheeja, R.Y. and T. Murugesan, 2002. Studies on biodegradation of phenol using response surface methodology. J. Chem. Technol. Biotechnol., 77: 1219-1230.

Shourian, M., K.A. Noghabi, H.S. Zahiri, T. Bagheri and G. Karballaei et al., 2009. Efficient phenol degradation by a newly characterized Pseudomonas sp. SA01 isolated from pharmaceutical wastewaters. Desalination, 246: 577-594. DOI: $10.1016 / \mathrm{j}$. desal.2008.07.015

Solyanikova, I.P. and L.A. Golovleva, 2004. Bacterial degradation of chlorophenols: Pathways, biochemica and genetic aspects. J. Environ. Sci. Health B, 39: 333-351. DOI: 10.1081/pfc-120035921

Sridevi, V., M.V. Lakshmi, A.V. Swamy and M. N. Rao, 2011. Implementation of response surface methodology for phenol degradation using Pseudomonas putida (NCIM 2102). J. Bioremediat. Biodegradat. DOI: 10.4172/2155-6199.1000121

Tziotzios, G., M. Teliou, V. Kaltsouni, G. Lyberatos and D.V. Vayenas, 2005. Biological phenol removal using suspended growth and packed bed reactors. Biochem. Eng. J., 26: 65-71.

DOI: $10.1016 /$ j.bej.2005.06.006

Varma, R.J. and B.G. Gaikwad, 2009. Biodegradation and phenol tolerance by recycled cells of Candida tropicalis NCIM 3556. Int. Biodeteriorat. Biodegradat., 63: 539-542.

DOI: 10.1016/j.ibiod.2009.01.001 
Wang, S.G., X.W. Liu, H.Y. Zhang, W.X. Gong and X.F. Sun et al., 2007a. Aerobic granulation for 2,4dichlorophenol biodegradation in a sequencing batch reactor. Chemosphere, 69: 769-775.

DOI: $10.1016 /$ j.chemosphere.2007.05.026

Wang, Y., Y. Tian, B. Han, H.B. Zhao and J.N Bi et al., 2007b. Biodegradation of phenol by free and immobilized Acinetobacter sp. strain PD12. J. Environ. Sci., 19: 222-225.

DOI: 10.1016/S1001-0742(07)60036-9

Wu, S., X. Yu, Z. Hu, L. Zhang and J. Chen, 2009. Optimizing aerobic biodegradation of dichloromethane using response surface methodology. J. Environ. Sci., 21: 1276-1283.

DOI: $10.1016 / \mathrm{S} 1001-0742(08) 62415-8$

Yao, Y., Z. Lv, H. Min, Z. Lv and H. Jiao, 2009. Isolation, identification and characterization of a novel Rhodococcus sp. strain in biodegradation of tetrahydrofuran and its medium optimization using sequential statistics-based experimental designs. Bioresource Technol., 100: 2762-2769.

DOI: $10.1016 /$ j.biortech.2009.01.006
Ye, F.X. and D.S. Shen, 2004. Acclimation of anaerobic sludge degrading chlorophenols and the biodegradation kinetics during acclimation period. Chemosphere, 54: 1573-1580.

DOI: $10.1016 /$ j.chemosphere.2003.08.019

Zhao, G., L. Zhou, Y. Li, X. Liu and X. Ren et al., 2009. Enhancement of phenol degradation using immobilized microorganisms and organic modified montmorillonite in a two-phase partitioning bioreactor. J. Hazardous Mater., 169: 402-410.

DOI: 10.1016/j.jhazmat.2009.03.110 